\title{
Optimization of Composite Protein- Lipid Film by Ohmic Heating using Mixture Design
}

\author{
V. Ajesh Kumar ${ }^{1 *}$, M. Pravitha ${ }^{1}$ and Akash Pare ${ }^{2}$ \\ ${ }^{1}$ ICAR-Central Institute of Agricultural Engineering, Bhopal, India \\ ${ }^{2}$ Indian Institute of Food Processing Technology, Thanjavur, India \\ *Corresponding author
}

\begin{abstract}
Keywords
Protein lipid film, Soybean, Ohmic heating. Mixture design

Article Info

Accepted:

04 February 2019

Available Online:

10 March 2019

A B S T R A C T

Protein-lipid film is a very popular food material which can be prepared from various protein foods. A remarkable example of the protein-lipid film is a traditional soybean food which is a cream-yellow bland flavoured surface film of high nutritional value (soy protein-lipid film, designated as Yuba or soymilk skin), which is formed during the heating of soymilk. The protein digestion rate of the protein-lipid film is almost $100 \%$. The objective of this study was to optimize the production of the composite protein lipid film using ohmic heating method, which has a significant effect on the quality of film produced over the conventional water bath heating, from blends of soy milk, peanut milk and fresh corn milk according to D-optimal mixture design approach. Results demonstrated that soy milk, peanut milk and fresh corn milk had noticeable effect on yield and protein content of the film. Multi-response optimization using all of the regression models was performed with the Design-Expert software, using its defaults settings to construct a desirability score that balances all of the fitted models. The methodology of the desired function was applied and the optimum level of various process variables was obtained as, Soy milk 0.57 Peanut milk 0.4 and corn milk 0.03 , which gives the maximum of $21.44 \mathrm{~g} / 100 \mathrm{ml}$ yield and $56.83 \%$ protein content with overall desirability value of 0.81 .Other responses like colour, rehydration capacity and thickness of the film found to have no significant effect with the different milk formulations
\end{abstract}

\section{Introduction}

Edible films can be used for versatile food products to reduce loss of moisture, restrict absorption of oxygen, lessen migration of lipids, improve mechanical handling properties, provide physical protection, and/or offer an alternative to the commercial packaging materials. The films can enhance the organoleptic properties of packaged foods provided that various components (such as flavourings, colourings and sweeteners) are used. The films can function as carriers for antimicrobial and antioxidant agents (Bourtoom, 2009). The films can also be used for individual packaging of small portions of food, particularly products that are currently not individually packaged for practical reasons. These include pears, beans, nuts and strawberries. In a similar application they 
also can be used at the surface of food to control the diffusion rate of preservative substances from the surface to the interior of the food. When soymilk is heated in flat, shallow, open pans at about $90^{\circ} \mathrm{C}$, a creamyellow, bland flavoured surface film gradually forms. The films, which is also known as Yuba, are successively removed from the surface, hung to air dry and marketed or stored as dried sheets, sticks and chips, or further fabricated into texturized food products. The films can be consumed directly as an ingredient of soups or used as a sheet for wrapping and shaping ground meats or vegetables into various forms. The protein digestion rate of proteinlipid film is almost $100 \%$. Protein-lipid film is a very popular food material in China as well as Japan. The yield per year in China was over 200,000 tons at the end of 20th century. The formation mechanism of proteinlipid film is entirely different from that of tofu which is another traditional soybean food.

Tofu is a kind of gel formed by the addition of solidification reagents such as $\mathrm{CaCO}_{3}$ and is mainly composed of protein, lipid and water. On the other hand, proteinlipid film is formed as a result of endothermic polymerization of heat denatured proteins or lipoprotein monomers at the liquid surface promoted by surface dehydration. Heating of soymilk leads to a change in the threedimensional structure of proteins and results in exposing sulphydryl groups and hydrophobic side chains. In tofu processing, proteins create a framework, while lipid and water are buried in networks. Therefore, high protein concentration is beneficial for tofu gel formation. During the film formation of Yuba, lipid acts as a surfactant which moves to the air/water interface and interacts with proteins by hydrophobic interactions. Furthermore, some of the lipids can be buried in a protein network structure during the protein- lipid film formation. It has also been widely suggested that protein creates a framework in the protein-lipid film structure, while lipids are dispersed in it as droplets. The concentration of protein lipid film in the soy milk which is ultimately depends on the soybean cultivar has dependence on the productivity of protein-lipid film formation (Enujiugha, 2013). Various reports have shown the effect of protein and lipid contents on the productivity of protein-lipid film. Wu and Bates (1972) observed that poor productivity of protein lipid film occurred in systems with low protein-lipid ratio under 1.00. The suitability of soybean cultivars for protein- lipid film production is still not clear. Soybeans with high protein content are selected generally selected for tofu production. However, since the formation mechanism of protein-lipid film is different from that of tofu, there may be some other factors than protein content which are dominant in protein-lipid film productivity.

In view of the potential value of proteinlipid films for both their structural and nutritional properties and the ease with which such films can be formed from dilute aqueous protein-lipid dispersions, it was deemed worthwhile to investigate a few of the numerous protein sources presently receiving considerable attention. In this study of film formation employing various agricultural and industrial protein and lipid ingredients, designed to establish conditions and blends for maximal yield and protein recovery, with desirable quality attribute like colour and thickness.

Wu et al., (1973) conducted a film formation studies employing several agricultural and industrial protein and lipid ingredients, designed to establish conditions and blends for maximal protein recovery, film formation rate and mechanical strength. Oilseeds such 
as peanuts and cottonseed are useful proteinlipid film ingredients; particularly in the high lipid content is reduced by oil recovery or improved by adding functional protein from soy, whey or casein derivatives. These films can be used as substitute to meat. Wu et al., (1975) conducted a study to create proteinlipid film as a substitute to meat, the sheets are soaked inappropriate flavouring solutions such as soy or meat broths, layered several sheets thick, rolled tightly, wrapped firmly in cloth, and tied to retain internal pressure. The rolls are then steamed for about $1 \mathrm{hr}$ and consumed as a main dish. An alternate texturization process involves placing layers of moist, flavoured films in aluminium moulds shaped like whole chicken or fish. The centre of the mould may be stuffed with film remnants, or fitted with a wooden plug, thus providing a hollow space for subsequent stuffing ingredients. The mould is closed and manual pressure applied, resulting in a firm meat-like texture of desired shape. Although they employ low-cost raw materials, extensive hand labour is required. Consequently, such fabrication techniques are not conducive to the production of uniform quality, high volume food materials.

Ohmic heating is a new method used for the production of protein-lipid film. The conventional heating method of producing protein-lipid film is water bath heating, in which it is difficult to control the heating temperature. Moreover, it is difficult to heat soybean milk evenly and the yield and quality of protein- lipid film are affected heavily. These problems can be addressed using ohmic heating method which ensures uniform heating and control over temperature. The ohmic heating method has significant effect on yields, film formation rates, PIE, whiteness and rehydration capacities of protein-lipid films compared to conventional water bath heating. Yield and
PIE by ohmic heating was higher than those by water bath heating. Also film formation rate and rehydration capacity of protein-lipid film was increased by ohmic heating (Lei et al., 2007)

The protein lipid film prepared from soy bean doesn't contain all the essential amino acids. Several combinations of protein sources can be blended in different proportions to develop a new product with altered characteristics and enhanced nutritional profile. So in order to enrich the protein lipid film, we considered protein sources like peanut and maize with soybean for developing composite protein-lipid films. In other way the extraction of protein component from sources like maize are difficult. So the method of surface film formation will enable us to extract the protein from the same. Considering all the facts discussed above and pointing out the necessity of developing a protein rich blended film, the main objective of this study has been selected as production of composite protein-lipid film from soy-peanut - corn milk blend using ohmic heating method.

\section{Materials and Methods}

\section{Materials}

Soybean (Glicene $\max (\mathrm{L})$ ), CO-1 variety, Peanut and fresh Corn were procured from the local market of Thanjavur and were kept at cold $\left(4-8^{\circ} \mathrm{C}\right)$ storage until used for the extraction of milk. The moisture content of the soybean and peanut determined by hot air oven method were $14.5 \%$ and $8 \%$ respectively.

\section{Ohmic heating Setup}

Ohmic heating set up present in the Incubation centre of IICPT (Fig. 1) has been used for this study. It consist of power supply (generator) for producing electricity, 
electrodes connected to power supply system which facilitate the electric current to pass through the food material. It also has the facility to change the electric field strength $(\mathrm{V} / \mathrm{cm})$ and frequency. The temperature of the system can also be measured using thermocouples provided.

The laboratory scale ohmic heating tray, with a capacity of $500 \mathrm{ml}$ (Fig. 2) is used for heating the milk blends. It is made of acrylic sheet of $6 \mathrm{~mm}$ thickness.

\section{Sample preparation}

Soymilk extraction plant installed at IICPT Thanjavur was used for the extraction milk by following the standard operating procedures of the plant. Definite amount of soy bean, peanut and fresh corn were cleaned and soaked in 4 times of tap water for 12 hours at $4^{\circ} \mathrm{C}$. This soaked sample were grinded and filtered using soy milk extraction plant. The Soluble solid content of the milks were measured with digital refractometer and adjusted to 7.5, 7.5 and $2.5^{\circ}$ Brix for soy milk, peanut milk and fresh corn milk respectively by adding distilled water. Blends of milk samples with different proportion were made according to the experimental design.

\section{Film formation}

$500 \mathrm{ml}$ of milk formulation prepared according to the experimental design was poured in to the ohmic heating tray. The ohmic heating parameters were set as 12 EFS and $40 \mathrm{~Hz}$. The temperature of composite milk was controlled within $85 \pm 3{ }^{\circ} \mathrm{C}$. After7$8 \mathrm{~min}$, the first film was formed on the surface. An L shaped plastic rod was slipped under the film and then gently lifted, resulting in a sheet film hung upon the rod (Fig. 3). The film sheet was drained for a few seconds and then hung to air dry(ambient dehydration) for
1 min before being taken down from the rod. Every sheet of film was numbered according to the sequence of removal.

\section{Physico-chemical analysis}

\section{Measurement of total soluble solid (TSS)}

Total soluble solids (TSS) of the mixture was determined using a digital refractometer, (Model: RX-7000; Make: Atago, Japan) which has an accuracy of $\pm 0.000010 \mathrm{nD}$ and \pm 0.005 . ${ }^{\circ}$ Brix. Few drops of the sample were placed on the sample slot of refractometer and the TSS of the sample was recorded and expressed in ${ }^{\circ}$ Brix. Refractive index (nD) and brix varies in the range of 1.32422 to 1.70000 and 0.00 to $100.00 \%$ respectively.

\section{Measurement of colour}

CIE colour parameters $\mathrm{L}^{*}$ (Lightness); $\mathrm{a}^{*}$ (red-green) and $b^{*}$ (yellow-blue) of the sample are estimated using spectrophotometer (Model: ColorFlex EZ; Make: Hunterlab, USA). Whiteness was used to compare the colour difference between different protein lipid films. The equation for calculating whiteness wasby proposed by L. Lei et al., (2007)

Whiteness $=L^{*}-3 b^{*}$

\section{Measurement of film thickness}

Thickness of double layer of protein lipid films was measured by using vernier caliper. The vernier caliper has least count of $0.1 \mathrm{~mm}$. Prior to the measurement, films were dried in ambient temperature for 10-12 hr.

\section{Proximate analysis}

Total protein (Nitrogen x6.25) was analysed using approved methods of Kjeldahl (AOAC, 1990) in automatic machine (Model: Kelplus 
Classic DX; Make: Pelican, India).Fat content of the protein-lipid film was analysed using Soxhlet apparatus (Model: Socsplus- SCS06 AS; Make: Pelican, India).n-hexane was used as solvent for fat extraction.

\section{Preliminary experiments}

Preliminary experiments were conducted to find the suitable maximum and minimum values for the ingredients of the blend milk, and also to find the suitable ohmic heating parameter for the production of the better protein-lipid film formation. Shivasankary et al., (2015) used $12 \mathrm{~V} / \mathrm{cm}$ of Electric field strength and $40 \mathrm{~Hz}$ frequency as optimized parameter. In the preliminary experiment it is observed that $12 \mathrm{~V} / \mathrm{cm}$ EFS and $40 \mathrm{~Hz}$ frequency were giving good results with different combination of milk blends. For the optimization of soy- peanut-corn milk of formulations variable like protein content of the film, colour, thickness, rehydration capacity and yield were dependent parameters.

\section{Experimental design}

Based on preliminary studies, fixed ohmic heating parameters, independent variable with their ranges and dependent variable were selected for the final experiment. The fractions of components in a mixture cannot be changed independently, and for this situation the mixture designs are appropriate. The nonnegative fractions must add up to 1 (Montgomery, 2009). Using Optimal Mixture design (Cornell, 1983) sixteen milk formulation were processed by mixing the three basic ingredients; soy milk, peanut milk and fresh corn milk. A mixture design was programmed using Design Expert 10 software, to obtain 16 design points from three components. The lower limit (soy milk0.4 , peanut milk-0.2. corn milk- 0.0) and upper bound constraints (soy milk- 0.6, peanut milk-0.4. corn milk- 0.2) for each mixture component were used to generate the design. Selected components and their constraints for the mixture design of experiments are shown in table 1 .

\section{Results and Discussion}

\section{Yield}

Yield of the protein-lipid film for different milk blends varies from 12.26 to $21.44 \mathrm{~g}$ $1100 \mathrm{ml}$ of milk. All the milk formulations showed significant difference $(\mathrm{p}<0.05)$ in the yield of the sample. The regression models obtained by the measured values were analyzed and fitted to various models. In general, exploration of a fitted response surface may produce poor or misleading results, unless the model exhibits a good fit, which makes checking of the model adequacy essential (Table 2). The adequacy of model summary output indicates that, the cubic model was highly significant statistically for effect variables on yield. Cubic model was found to have maximum "Adjusted R-Squared" and "Predicted RSquared" values and hence the cubic model was chosen for further analysis (Table 3).

The third-order polynomial equation in terms of coded units the following equations was generated by the application of response surface methodology to obtain the empirical relationship between the experimental results on the basis of Mixture design.

Yield $(\mathrm{gm} / 100 \mathrm{ml}$ milk $)=-146.654 * \mathrm{~A}+$ $116.706 * \mathrm{~B}+99.0093 * \mathrm{C}+113.692 * \mathrm{AB}+$ $151.342 * \mathrm{AC}+-376.092 * \mathrm{BC}+136.715 *$ $\mathrm{ABC}+95.3469 * \mathrm{AB}(\mathrm{A}-\mathrm{B})+498.712 *$ $\mathrm{AC}(\mathrm{A}-\mathrm{C})+-108.741 * \mathrm{BC}(\mathrm{B}-\mathrm{C})$

In general, proceeding with exploration and optimization using a fitted response surface may produce unreliable results unless the 
model exhibits an adequate fit (Omwamba and $\mathrm{Hu}, 2009)$. This makes the checking of model adequacy essential.

The results of analysis of variance (ANOVA) for the optimal mixture design are shown in Table 4. The ANOVA of Cubic model demonstrates that the model is highly significant as evident from Fisher's F-test value being 68.69. The coefficient of determination, which is a measure of degree of fit, was 0.990 for yield.

The adjusted $\mathrm{R}^{2}$ value obtained is 0.976 . Higher the value of coefficient of variation (CV) shows lower reliability of experiment. Here, a lower value of CV (2.94) indicated a greater reliability of the experiments performed.

\section{Protein}

Total protein percentage of the film varies significantly with dependent variables. Value of protein percentage varies from 52.2 to $61.03 \%$. All the milk formulations showed significant difference $(\mathrm{p}<0.05)$ in the protein percentage of the sample. Model summary output indicates that, the special Quartic Vs Quadratic model was highly significant statistically for effect variables on Protein percentage of samples.

Protein $(\%)=69.3534 * \mathrm{~A}+75.5424 * \mathrm{~B}+$ $47.8811 * \mathrm{C}+-49.3684 * \mathrm{AB}+-20.0368 *$ $\mathrm{AC}+-35.9162 * \mathrm{BC}+-38.4312 * \mathrm{~A}^{2} \mathrm{BC}+-$ $362.907 * \mathrm{AB}^{2} \mathrm{C}+879.771 * \mathrm{ABC}^{2}$

The fit of these empirical models was also checked by the coefficient of determination $\left(\mathrm{R}^{2}\right)$, the adjusted- $\mathrm{R}^{2}$, the predicted- $\mathrm{R}^{2}$, and the Coefficient of variation (CV), see Table 5 . Adjusted $\mathrm{R}^{2}$ is 0.963 and Predicted $\mathrm{R}^{2}$ is 0.920 meaning that the full model is estimated to explain about $92.37 \%$ of the variability in new data. The coefficient of variation value of protein percentage is found to be very low, 0.93 . The ANOVA of special Quartic Vs Quadratic model demonstrates that the model is highly significant as evident from Fisher's F-test value being 50.67 (Table 6).

\section{Colour}

Colour plays a major role in consumer acceptability of protein-lipid films. Colour values are compared using whiteness $\left(\mathrm{L}^{*}\right.$ $\left.3 b^{*}\right)$ value of the film. Average $L^{*}, b^{*}$ and $L^{*}-3 b^{*}$ value of $1^{\text {st }}, 3^{\text {rd }}$, layer were displayed in Table 7.

The whiteness value varied from -29.24 from 1.71. Colour didn't have significant effect on the whiteness of protein-lipid film even though the whiteness was reduced by increase in corn milk content. The corn milk plays major role in determining the colour of the films.

\section{Thickness}

Thickness of the protein lipid film was measured using the vernier calliper after drying in ambient condition for 10-12 hours.

The thickness of the developed film varies from 0.70 to $1.01 \mathrm{~mm}$. Thickness of the protein lipid film is not significantly affected by the independent variables. Table 8 shows the average thickness value protein-lipid films of different milk formulations.

\section{Rehydration capacity}

Rehydration capacity was an important character of protein-lipid film because it was generally stored and sold in a dried condition. During rehydration, the amount of water absorbed increased fast in the time range of 115 min. 
At about 12min, it reached the maximum. At last, the protein- lipid film regained a considerable percentage of its original moisture content. However rehydration capacity is not significantly affected by independent variable. The rehydration capacity of protein- lipid film, measured percentage weight gain, for 10-15 minutes, for every formulation is shown in Table 9 .

\section{Optimal formulation of the overall} Responses

The process parameters were optimized to achieve maximum. Multi response optimization using all of the regression models was performed with the DesignExpert software, using its defaults settings to construct a desirability score that balances all of the fitted models. The Figure 6 shows the formulation that was considered optimal, along with contours of the desirability score.

The methodology of desired function was applied and the optimum level of various process variables were obtained as, Soy milk 0.576 Peanut milk 0.4 and corn milk 0.023 , which gives maximum of $21.44 \mathrm{~g}$ yield and $56.83 \%$ protein content with overall desirability value of 0.81 (Fig. 4-6).

Table.1 Component constraints

\begin{tabular}{|l|l|}
\hline Component & Fraction restriction \\
\hline Soy milk (A) & $\mathbf{0 . 4} \leq \mathrm{A} \leq \mathbf{0 . 6}$ \\
\hline Peanut milk (B) & $\mathbf{0 . 2} \leq \mathrm{B} \leq \mathbf{0 . 4}$ \\
\hline Corn milk (C) & $\mathbf{0 . 0} \leq \mathrm{C} \leq \mathbf{0 . 2}$ \\
\hline
\end{tabular}

Table.2 Model adequacy indicators for responses

\begin{tabular}{|l|c|c|c|c|}
\hline Response & $\mathbf{R}^{2}$ & Adj-R $^{2}$ & Pred-R $^{2}$ & CV \\
\hline Yield & 0.9904 & 0.9760 & 0.9463 & $\mathbf{2 .}$ \\
\hline Protein & $\mathbf{0 . 9 8 3 0}$ & $\mathbf{0 . 9 6 3 6}$ & $\mathbf{0 . 9 2 0 9}$ & $\mathbf{0 .}$ \\
\hline
\end{tabular}

Table.3 Model summary statistics

\begin{tabular}{|l|c|c|c|c|c|}
\hline \multicolumn{1}{|c|}{ Source } & $\begin{array}{c}\text { Sequential } \\
\text { p-value }\end{array}$ & $\begin{array}{c}\text { Lack of Fit } \\
\text { p-value }\end{array}$ & $\begin{array}{c}\text { Adjusted } \\
\text { R-Squared }\end{array}$ & $\begin{array}{c}\text { Predicted } \\
\text { R-Squared }\end{array}$ & \\
\hline Linear & 0.4295 & 0.0002 & -0.0132 & -0.2957 & \\
\hline Quadratic & 0.0019 & 0.0022 & 0.6859 & 0.5395 & \\
\hline Special Cubic & 0.4409 & 0.0017 & 0.6745 & 0.5145 & \\
\hline$\underline{\text { Cubic }}$ & $\underline{0.0003}$ & $\underline{0.7404}$ & $\underline{0.9760}$ & $\underline{0.9463}$ & $\underline{\text { Suggested }}$ \\
\hline Sp Quartic vs & 0.0187 & 0.0123 & 0.8833 & 0.5675 & \\
\hline Quartic vs Cubic & 0.7404 & & 0.9719 & & Aliased \\
\hline Ouartic vs Sp & $\mathbf{0 . 0 1 2 3}$ & & $\mathbf{0 . 9 7 1 9}$ & & Aliased \\
\hline
\end{tabular}


Table.4 ANOVA for Yield of formulated milk blends

\begin{tabular}{|c|c|c|c|c|c|c|}
\hline Source & SS & df & MS & F Value & p-value Prob > F & \\
\hline Model & 119.20 & 9 & 13.24 & 68.69 & $<0.0001$ & significant \\
\hline${ }^{1}$ Linear Mixture & 14.67 & 2 & 7.34 & 38.05 & 0.0004 & \\
\hline$A B$ & 0.86 & 1 & 0.86 & 4.43 & 0.0798 & \\
\hline$A C$ & 1.02 & 1 & 1.02 & 5.29 & 0.0611 & \\
\hline$B C$ & 9.89 & 1 & 9.89 & 51.27 & 0.0004 & \\
\hline$A B C$ & 0.33 & 1 & 0.33 & 1.73 & 0.2359 & \\
\hline$A B(A-B)$ & 1.02 & 1 & 1.02 & 5.31 & 0.0608 & \\
\hline$A C(A-C)$ & 13.57 & 1 & 13.57 & 70.39 & 0.0002 & \\
\hline$B C(B-C)$ & 1.36 & 1 & 1.36 & 7.05 & 0.0378 & \\
\hline Residual & 1.16 & 6 & 0.19 & & & \\
\hline Lack of Fit & 0.028 & 1 & 0.028 & 0.12 & 0.7404 & not significant \\
\hline Pure Error & 1.13 & 5 & 0.23 & & & \\
\hline Cor Total & 120.36 & 15 & & & & \\
\hline
\end{tabular}

Table.5 Model summary statistics

\begin{tabular}{|l|c|c|c|c|c|}
\hline Source & $\begin{array}{l}\text { Sequential } \\
\text { p-value }\end{array}$ & $\begin{array}{l}\text { Lack of Fit } \\
\text { p-value }\end{array}$ & $\begin{array}{l}\text { Adjusted } \\
\text { R-Squared }\end{array}$ & $\begin{array}{l}\text { Predicted } \\
\text { R-Squared }\end{array}$ & \\
\hline Linear & 0.1871 & 0.0008 & 0.1084 & -0.3562 & \\
\hline Quadratic & 0.0039 & 0.0075 & 0.6780 & 0.2417 & \\
\hline Special Cubic & 0.3226 & 0.0066 & 0.6810 & 0.2457 & \\
\hline Cubic & 0.0015 & 0.6114 & 0.9578 & 0.8677 & \\
\hline Sp Quartic vs Quadratic & $\underline{0.0003}$ & $\underline{0.8559}$ & $\underline{0.9636}$ & $\underline{0.9209}$ & Suggested \\
\hline Quartic vs Cubic & 0.6114 & & 0.9521 & & Aliased \\
\hline Quartic vs Sp Quartic & $\mathbf{0 . 8 5 5 9}$ & & $\mathbf{0 . 9 5 2 1}$ & & Aliased \\
\hline
\end{tabular}

Table.6 ANOVA for Protein of formulated milk blends

\begin{tabular}{|c|c|c|c|c|c|c|}
\hline Source & $\begin{array}{l}\text { Sum of } \\
\text { Squares }\end{array}$ & df & $\begin{array}{c}\text { Mean } \\
\text { Square }\end{array}$ & $\begin{array}{c}\text { F } \\
\text { Value }\end{array}$ & $\begin{array}{c}\text { p-value } \\
\text { Prob > F }\end{array}$ & \\
\hline Model & 116.14 & 8 & 14.52 & 50.67 & $<0.0001$ & significant \\
\hline $\begin{array}{l}{ }^{1} \text { Linear } \\
\text { Mixture }\end{array}$ & 26.85 & 2 & 13.43 & 46.87 & $<0.0001$ & \\
\hline$A B$ & 0.20 & 1 & 0.20 & 0.68 & 0.4360 & \\
\hline$A C$ & 0.027 & 1 & 0.027 & 0.093 & 0.7696 & \\
\hline$B C$ & 0.10 & 1 & 0.10 & 0.36 & 0.5654 & \\
\hline$A^{2} B C$ & 0.022 & 1 & 0.022 & 0.077 & 0.7896 & \\
\hline$A B^{2} C$ & 1.16 & 1 & 1.16 & 4.04 & 0.0843 & \\
\hline$A B C^{2}$ & 11.27 & 1 & 11.27 & 39.33 & 0.0004 & \\
\hline Residual & 2.01 & 7 & 0.29 & & & \\
\hline $\begin{array}{l}\text { Lack of } \\
\text { Fit }\end{array}$ & 0.12 & 2 & 0.060 & 0.16 & 0.8559 & $\begin{array}{l}\text { not } \\
\text { significant }\end{array}$ \\
\hline $\begin{array}{l}\text { Pure } \\
\text { Error }\end{array}$ & 1.88 & 5 & 0.38 & & & \\
\hline Cor Total & 118.14 & 15 & & & & \\
\hline
\end{tabular}


Table.7 Colour values

\begin{tabular}{|l|l|l|l|l|}
\hline Ru & L* & a* & b* & L*- \\
\hline R1 & 64.8 & 3.9 & 27.7 & - \\
\hline R2 & 65.6 & 4.2 & 30.1 & - \\
\hline R3 & 64.5 & 4.1 & 24.3 & - \\
\hline R4 & 64.0 & 3.8 & 23.7 & - \\
\hline R5 & 63.0 & 3.5 & 25.6 & - \\
\hline R6 & 63.6 & 4.3 & 30.9 & - \\
\hline R7 & 63.4 & 3.6 & 25.9 & - \\
\hline R8 & 70.1 & 3.6 & 26.2 & - \\
\hline R9 & 65.5 & 3.5 & 26.8 & - \\
\hline R1 & 65.1 & 2.9 & 27.1 & - \\
\hline R1 & 70.4 & 2.5 & 22.9 & $\mathbf{1 . 7}$ \\
\hline R1 & 64.3 & 3.7 & 23.7 & - \\
\hline R1 & 69.1 & 3.7 & 26.3 & - \\
\hline R1 & 64.5 & 3.2 & 27.8 & - \\
\hline R1 & 64.2 & 3.2 & 24.2 & - \\
\hline R1 & $\mathbf{7 0 . 2}$ & $\mathbf{2 . 5}$ & $\mathbf{2 2 . 9}$ & $\mathbf{1 . 4}$ \\
\hline & & & - \\
\hline
\end{tabular}

Table.8 Thickness values

\begin{tabular}{|l|l|l|l|l|l|l|l|l|l|l|l|l|l|l|l|l|}
\hline Run & R1 & R2 & R3 & R4 & R5 & R6 & R7 & R8 & R9 & R10 & R11 & R12 & R13 & R14 & R15 & R16 \\
\hline $\begin{array}{l}\text { Thickness } \\
(\mathbf{m m})\end{array}$ & $\mathbf{0 . 9 2}$ & $\mathbf{0 . 8 2}$ & $\mathbf{0 . 9 1}$ & $\mathbf{1 . 0 1}$ & $\mathbf{0 . 7 4}$ & $\mathbf{0 . 7 7}$ & $\mathbf{0 . 7 6}$ & $\mathbf{0 . 8 6}$ & $\mathbf{0 . 9 4}$ & $\mathbf{0 . 9 7}$ & $\mathbf{0 . 7 2}$ & $\mathbf{0 . 9 9}$ & $\mathbf{0 . 8 0}$ & $\mathbf{0 . 7 8}$ & $\mathbf{0 . 7 2}$ & $\mathbf{0 . 7 0}$ \\
\hline
\end{tabular}

Table.9 Rehydration data, percentage gain in water

\begin{tabular}{|c|c|c|c|c|c|c|c|c|c|c|c|c|c|c|c|c|}
\hline $\begin{array}{c}\text { Time, } \\
\text { min }\end{array}$ & $\mathbf{R 1}$ & $\mathbf{R 2}$ & $\mathbf{R 3}$ & $\mathbf{R 4}$ & $\mathbf{R 5}$ & $\mathbf{R 6}$ & $\mathbf{R 7}$ & $\mathbf{R 8}$ & $\mathbf{R 9}$ & $\mathbf{R 1 0}$ & $\mathbf{R 1 1}$ & $\mathbf{R 1 2}$ & $\mathbf{R 1 3}$ & $\mathbf{R 1 4}$ & $\mathbf{R 1 5}$ & $\mathbf{R 1 6}$ \\
\hline $\mathbf{1 0}$ & 136.27 & 112.50 & 97.08 & 51.08 & 110.73 & 92.59 & 114.41 & 102.33 & 93.75 & 84.57 & 77.94 & 77.34 & 100.00 & 80.14 & 135.48 & $\mathbf{8 8 . 9 3}$ \\
\hline $\mathbf{1 2}$ & 143.52 & 118.27 & 106.57 & 59.71 & 121.47 & 101.65 & 122.52 & 106.20 & 103.33 & 92.57 & 86.83 & 85.25 & 109.63 & 84.25 & 141.94 & $\mathbf{9 8 . 2 1}$ \\
\hline $\mathbf{1 4}$ & 148.70 & 125.96 & 112.04 & 66.91 & 124.86 & 104.94 & 125.23 & 111.63 & 109.17 & 98.86 & 95.73 & 93.53 & 110.55 & 86.99 & 143.23 & $\mathbf{1 0 8 . 9 3}$ \\
\hline $\mathbf{1 6}$ & $\mathbf{1 5 2 . 8 5}$ & $\mathbf{1 2 5 . 9 6}$ & $\mathbf{1 1 2 . 0 4}$ & $\mathbf{7 0 . 7 4}$ & $\mathbf{1 2 5 . 4 2}$ & $\mathbf{1 0 5 . 7 6}$ & $\mathbf{1 2 5 . 2 3}$ & $\mathbf{1 1 4 . 7 3}$ & $\mathbf{1 1 0 . 4 2}$ & $\mathbf{1 0 0 . 0 0}$ & $\mathbf{9 5 . 7 3}$ & $\mathbf{9 8 . 2 0}$ & $\mathbf{1 1 3 . 7 6}$ & $\mathbf{8 7 . 6 7}$ & $\mathbf{1 4 9 . 0 3}$ & $\mathbf{1 1 0 . 0 0}$ \\
\hline
\end{tabular}

Fig.1\&2 Ohmic heating Setup \& Ohmic heating tray
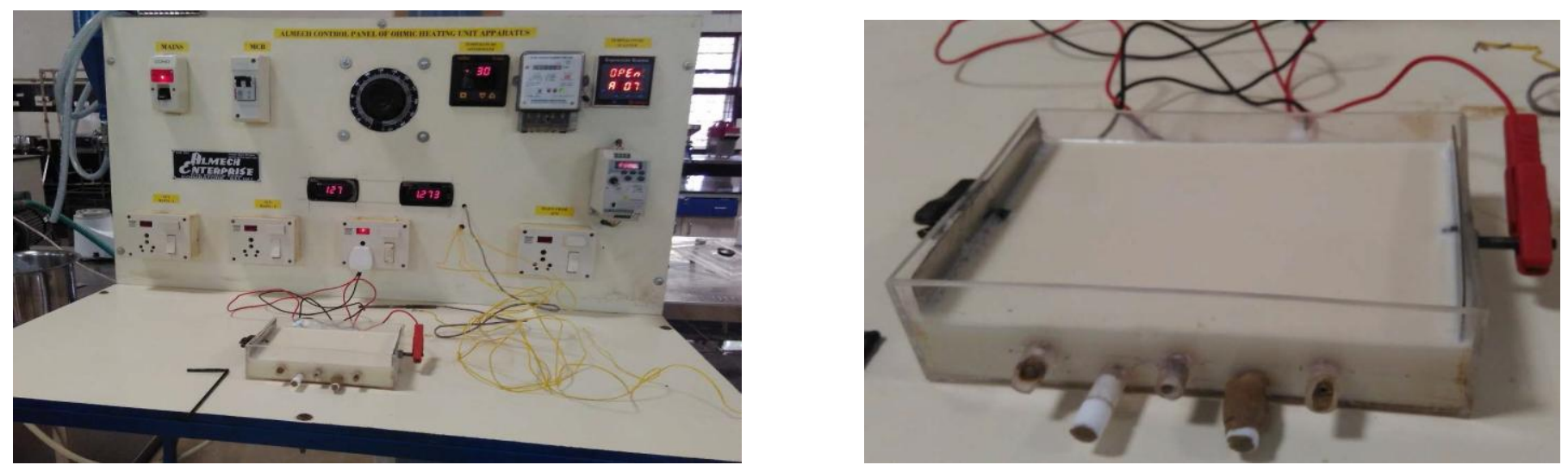
Fig.3 Freshly formed protein-lipid film

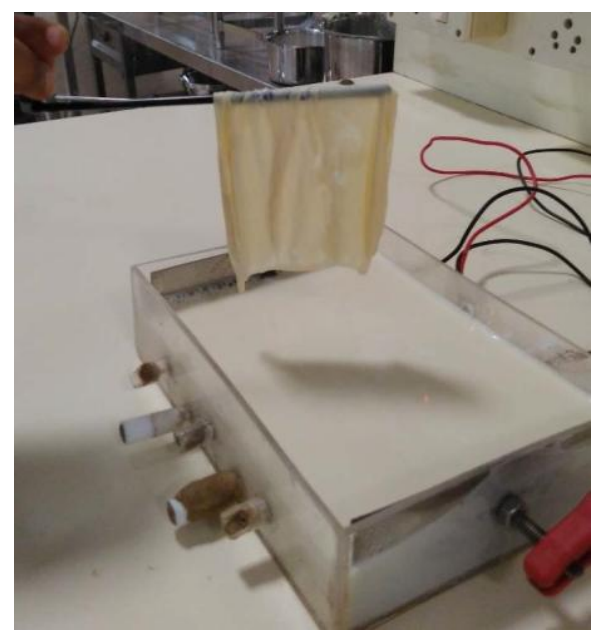

Fig.4 Contour plot of yield for different milk blends

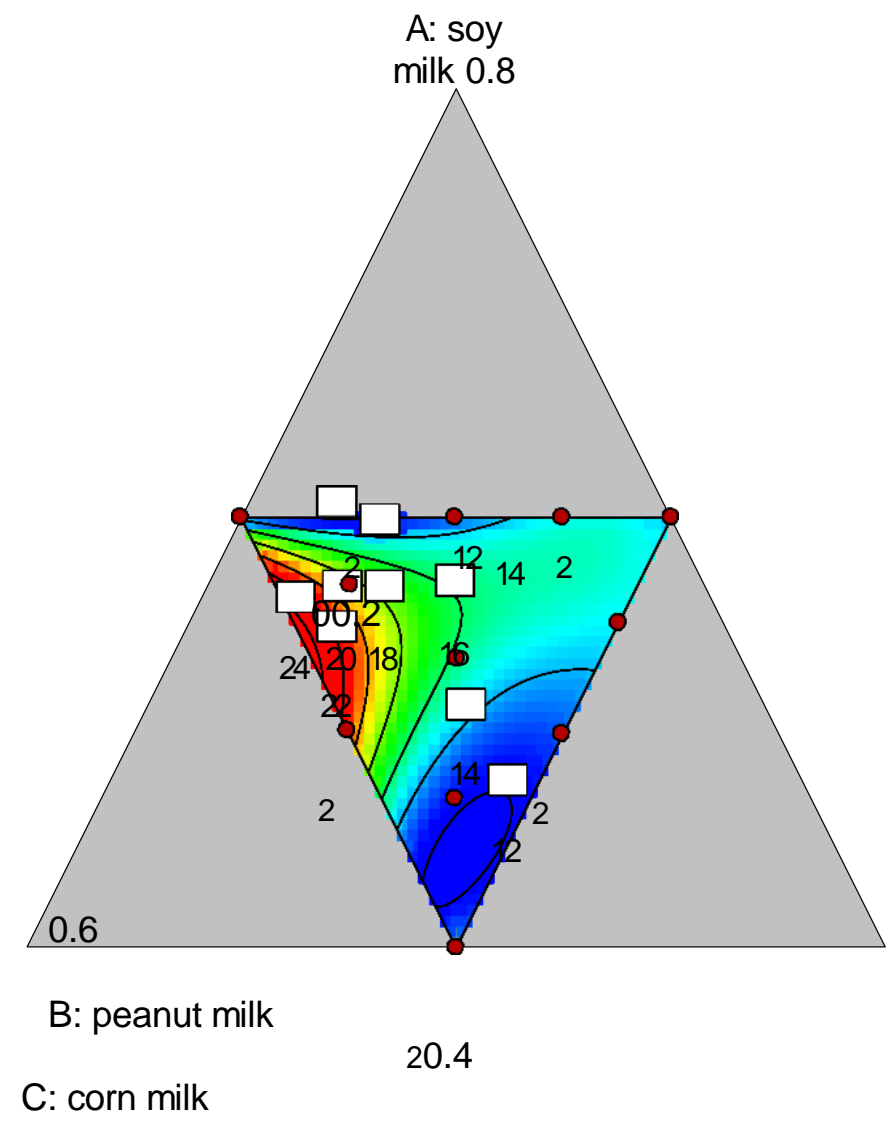


Fig.5 Contour plot of protein for different milk blends

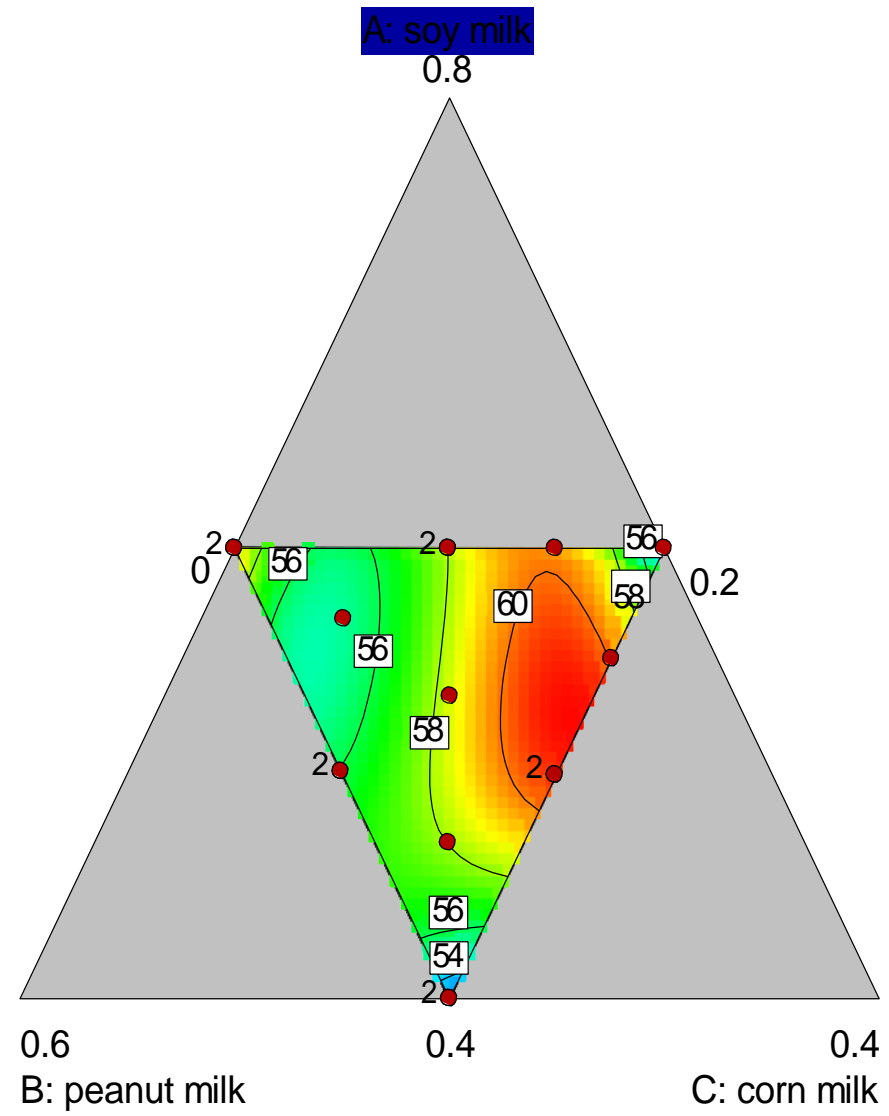

Fig.6 Contour plot of optimal formulation for overall desirability
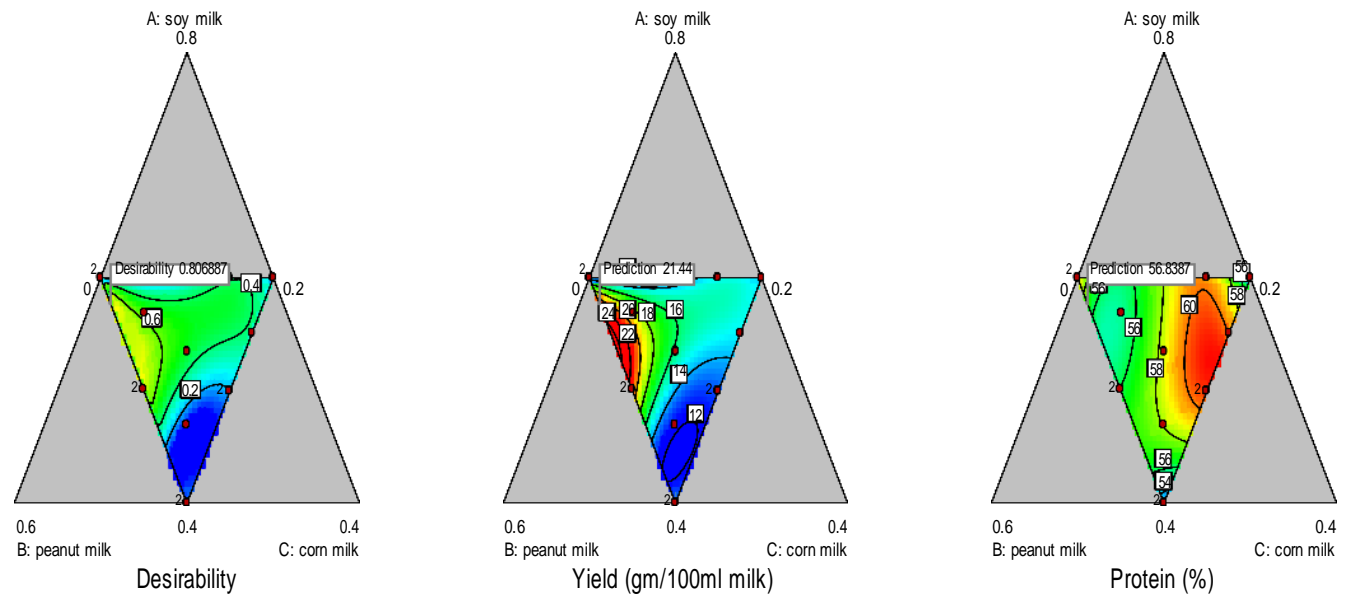

In conclusion, design and analysis of an optimal mixture experiment was used to obtain the optimal formulation of milk blend to develop composite protein lipid film from 
soy milk, peanut milk and corn milk. Analysis of variance revealed that not all the responses are significantly affected by the independent variables. Yield and protein content are the two responses which have significant effect on the formulated milk blends. Other responses had shown no effect with the formulated milk blends. Obtained optimum level of various process variables in fraction were as follows; Soy milk 0.576 , peanut milk 0.40 and 0.023 . The optimized combination different milk formulation results a maximum response of $21.44 \mathrm{~g}$ yield of the composite protein lipid film with protein content of $56.83 \%$ with a desirability value of 0.81 . Responses like colour, rehydration capacity and thickness of the film found to have no significant effect with the different milk formulations.

\section{References}

Bourtoom,(2009),. Edible protein films; Properties enhanced. International food Research Journal Vol.16 Vol. 1-9

Bradenburg, A. H., Weller, C. L. and Testin, R. F.. Edible films and coatings from soy protein. Journal of Food Science Vol.58 (1993), pp. 1086-1089.

Cao Y.M. and Chang K.C. (2001).Edible Films Prepared from Water Extract of Soybeans. Journal of Food Science Vol.67, Nr. 4, 1449-1454

Cornell. J. A. (1983). Experiment with Mixture: designs, Models, and the Analysis of Mixture data. John Wiley \& Sons

Enujiugha V. N., Ayodele R. O.,Seidu K. T. (2013).IJAFS 4 (1\&2), Pp 553-570
Long Lei, Han Zhi, Zhang Xiujin, Ishitani Takasuke, Li Zaigui. (2007). Effects of different heating methods on the production of protein-lipid film. Journal of Food Engineering 82 (2007) 292-297

Montgomery DC. (2009). Design and analysis of experiments. 7th ed. John Wiley \& Sons;

Omwamba, M., \& Hu, Q. (2009). Antioxidant capacity andantioxidative compounds in barley (Hordeum vulgare L.) grain optimized using response surface methodology in hotair roasting. European Food Research and Technology, 229,907-914

Prakash Maran, J., \& Manikandan, S. (2012). Response surface modeling and optimization of process parameters for aqueous extraction of pigments from prickly pear (Opuntia ficus-indica) fruit. Dyes and Pigments, 95, 465-472.

Qun. S, Xiujin. Z, Zhi. H, Zaigui LI and Masayoshi SAITO(2009).Productivity Properties of Protein-lipid Film (Yuba). JARQ 43 (1), 25-31

Shivashankary, M, Akash Pare, Yadav B. K., Santhakumaran. A, (2015). Estimation of Electrical Conductivity of Soymilk with Varied TSS Levels using Ohmic Heating. Trends in Bioscience, 8(3), 601-610.

Wu, L. C., \& Bates, R. P. (1973). Influence of ingredients upon edible protein-lipid film characteristics. Journal of Food Science, 38,783-787.

.Wu, L. C., \& Bates, R. P. (1975). ProteinLipid Films as Meat Substitutes. Journal of Food Science, 40, 160-163.

\section{How to cite this article:}

Ajesh Kumar, V., M. Pravitha and Akash Pare. 2019. Optimization of Composite ProteinLipid Film by Ohmic Heating using Mixture Design. Int.J.Curr.Microbiol.App.Sci. 8(03): 230241. doi: https://doi.org/10.20546/ijcmas.2019.803.030 